УДК $821.161 .1+82.95$ (Адамович-Оцуп)

Ли Ялинь, аспирант, Луганский национальный университет имени Тараса Шевченко (г. Старобельск)

\title{
Н. А. ОЦУП В ЛИТЕРАТУРНОЙ КРИТИКЕ Г. В. АДАМОВИЧА НА СТРАНИЦАХ «ЗВЕНА»
}

Ім'я М. Oиупа часто зустрічається у статтях Г. Адамовича. Автор не тільки звертається до розгляду творів, але $i$ дає характеристику його творчого методу, відзначаючи риси, що притаманні і йому самому. Критичні відгуки Адамовича свідчать про те, що йому близька лірика поета. Критик високо оиінював лірику поета, вважаючи 
головними в ній простоту, ясність, мужність, щиирість - те, щэо характеризує творчість близьких йому акмеистов.

Ключові слова: акмеїзм, критика, лірика, метод, рецепція, стаття.

Имя Н. Оиупа часто встречается в статьях Г. Адамовича. Автор не только обрашается к рассмотрению произведений, но и дает характеристику его творческого метода, отмечая черты, близкие ему самому. Критические отзывы Адамовича свидетельствуют о том, что ему близка лирика поэта. Критик высоко оценивал лирику поэта, считая главной в ней те простоту, ясность, мужественность, искренность, которые характеризуют творчество близких ему акмеистов.

Ключевые слова: акмеизм, критика, лирика, метод, рецепџия, статья.

Adamovich wrote articles about Otsup oftenly. Author looked at his compositions, poems and other lirycs. He discovered Otsup's creative methods. Adamovich saw in his creation similar to him features. Both critic and poet were acmeist. They both were very similar in their creation. Critic highly graduated lirics of poet, called simplicity, clarity, masculinity and candor as main features of his creations.

Keywords: acmeism, critics, lyrics, method, reception, article.

Творчество Н. А. Оцупа занимает особое место в литературе русского зарубежья. Его поэзия, проза, литературная критика неизменно вызывали интерес читателей. Что касается оценки Адамовичем творчества Оцупа, то критик, знавший автора по дореволюционным временам и считавший его таким же учеником Гумилёва, каким был и сам, всегда поддерживал писателя, следил за его эволюцией. Сегодня изучение рецепции Адамовичем творчества Оцупа еще не стало объектом внимания исследователей, хотя мы считаем важным изучение этого аспекта для понимания наследия Адамовича. Все это обусловливает актуальность и цель нашей статьи - изучить рецепцию Адамовичем творчества Оцупа на страницах парижского «Звена».

Имя Оцупа неоднократно встречается в статьях Адамовича. Автор не только обращается к рассмотрению произведений, но также дает характеристику его творческого метода, отмечая черты, близкие ему самому. В статье, посвященной рассмотрению подборки стихотворений авторов в «Современных записках» (1925), критик одним из достоинств лирики Оцупа называет полную противоположность произведениям Цветаевой, обусловленную особенностями его поэтического голоса: «Его стихи - полная противоположность цзветаевским. Они ослаблены ритмически, но в них безупречный выбор слов. Такую простоту и точность языка не часто встретишь. В стихах Оиупа стираются стилистические различия между 
поэзией и прозой: кони становятся лошадьми, уста - губами, альй цвет преврашцается в иявет красный. Какой это отдых и какая радость!» [Адамович 1998:124]. В этом отрывке Адамович называет достоинствами поэзии Оцупа качества, безусловно, близкие и ему самому. Поэт был одним из участников Цеха поэтов, так же, как и критик, считал себя учеником Гумилёва, продолжал его традиции. О. Верник справедливо указывает на моменты биографии Оцупа, которые подтверждают гумилёвское влияние не только на творчество, но и на жизненный путь автора: «Н. С. Гумилёв был ... поэтом, ... автором художественной прозы, критических и теоретических статей, литературоведческих и исторических исследований, переводчиком $и$ талантливым редактором, ... воином и путешественником. Эта характеристика подходит и для Очупа. Он основал журнал «Числа», несколько лет был редактором. Его перу принадлежит роман «Беатриче в аду», посвященный любви художника к начинающей актрисе. Во время Второй мировой войны Оцуп служил добровольцеем во фрранцузской армии (Гумилёв тоже ушел добровольцем на Первую мировую). Служба поэта была более трагична, чем у его предшественника: Оиуп почти два года находился в плену и дважды пытался бежать из конилагерей; с 1943 года активно работал в итальянском Сопротивлении. Приведеннье параллели, на наш взгляд, могут служить подтверждением и влияния Гумилёва на личность Оиупа, и близости их мировоззренческой позищии» [Верник 2010:211]. Он был первым, кто написал в русском зарубежье докторскую диссертацию о Гумилёве, в которой не только всесторонне исследовал творчество, но и подчеркнул, что его учитель занимает в истории литературы такое же место, как и А. С. Пушкин, М. Ю. Лермонтов, Ф. И. Тютчев. Все это свидетельствует о том, что Адамович, отношение которого к Гумилёву было сходным с оцуповским, разделял творческие предпочтения Оцупа и его поэзия, таким образом, не могла не вызвать одобрения критика.

Через год, в 1926, Адамович снова обратился к детальному рассмотрению поэзии Оцупа. На этот раз поводом стала его новая книга «В дыму» (1926). 
В начале статьи критик отмечает, что собранные произведения Оцупа были написаны в течении пяти лет, то есть за то время, когда творчество любого молодого автора эволюционирует, ищет свой индивидуальный путь, освобождается от посторонних влияний, поэтому существует опасность того, что книга может быть излишне пестрой, лишенной цельности. Вместе с тем, «В дыму» демонстрирует творческое единство собранных стихотворений: «У Oиупа есть тема. И, вероятно, будет стиль. В его книге ранние стихи значительно отличаются от позднейших, но все же в ней есть единство. И с этим единством связано то, что она оставляет впечатление истинно поэтическое» [Адамович 1999:7]. Адамович одобрительно оценивает включение Оцупом «прозаизмов» в стихотворения, которые помогли поэту избавиться от «футуристической разнузданности в звуках и образах». Для критика важна поэтическая точность и ясность оцуповской лирики (и это снова отсылает нас к его акмеистическим предпочтениям): «Он понял, что поэзия не может и не должна во внешнем своем выражении враждовать с разумом, что так называемые «поэтические вольности», m. е., вернее, поэтические бессмыслищы есть всегда слабость. Он попытался точным и отчетливым языком, забыв об инструментовках и метафорах, выразить то, что случайно тревожило его сознание» [Адамович 1999:7]. Обратим внимание, что в этих словах Адамович выражает прежде всего собственное художественное мировоззрение, свое негативное восприятие излишней, по его мнению, метафоричности, или, как он говорит, «футуро-имажинистской блажи». Ясность поэтической стилистики Оцупа, несомненно, привлекает Адамовича и дает ему основание для высокой оценки книги, хотя, как объективный критик, он указывает на недостатки поэтического синтаксиса, который близок «пастернако-цุветаевскому», но диссонирует с другими художественньми средствами стихотворений: «Словарь свеж и богат. Слабее синтаксис и вообще вся внутренняя логика речи: порой неясно даже, что к чему относится, что с чем связано. Это, может быть, допустимо в пастернако-цветаевской стилистике, основанной главным образом на 
слуховых сцеплениях. У Оиупа, при его явном стремлении к смысловой ясности, это, пожалуй, порок» [Адамович 1999:7]. В стихотворениях Оцупа отражен его опыт человека, переживающего катастрофизм своего времени и стремящегося найти точку опоры в историческом безумии эпохи. Такой опорой для него становится любовь, которая, находясь вне времени и пространства, соединяет поэта с лучшими традициями мировой любовной литературы, с творчеством Данте. Именно это Адамович считает лучшим в сборнике произведений Оцупа: «Катастрофыл, потрясения, разрыв мировых декораций - фон этих стихов. Впереди - любовь, похожая на обожествление какой-то новой Беатриче. Это проходит через всю книгу, и это лучшее, на мой взгляд, что в его книге есть» [Адамович 1999:8].

Ясность поэтического стиля Оцупа, которая привлекает Адамовича, является одним из проявлений акмеизма, так же, как и характерная для него мужественность мироощущения (вспомним, что в статье «Наследие символизма и акмеизм» Гумилёв определяет адамизм как «мужественно твердый и ясный взгляд на жизнь» [Гумилёв 1991:16]). Критик, рассматривая новые стихотворения поэта, вышедшие уже после сборника «В дыму», называет лучшими именно те, которые несут в себе акмеистическую поэтику. Наиболее точно этот взгляд Адамовича на творческую эволюцию Оцупа иллюстрирует следующая цитата: «Смутно чувствуется его рост, изменение его творческого образа. Смутное ощущение мне захотелось сделать ясным «проверить». И я увидел, что не ошибся. Из глубины, точнее, издалека идущуий голос. Множество препятствий на пути, - как будто луч, пробиваюшийся сквозь облака. "Современность» чуть-чуть слишком поверхностно, сличком по-брюсовски воспринятая, механика и фокстроты, аэропланы и револючии; затем любовь, «печальная страсть» на фоне этих роскошно размалеванньх декораций современности; затем воспоминания, как у Анненского, исторически-условные, но где Троя и Рим становятся именами какого-то исчезнувшего величия, исчезнувшей прелести; и, наконец, недоумение «человека», впервые как следует раскрывщего глаза и видящего, что мир прощце 
и сложнее, беднее и прекраснее всего того, что ему мерещуилось до сих пор» [Адамович 1999:90]. Цепочка ассоциаций, проводимая критиком, позволяет увидеть весь поэтический мир новых стихотворений Оцупа, в которых соединены влияния двух наиболее значимых для его учителя Гумилёва поэтов Брюсова и Анненского. По-видимому, эти имена важны и для Оцупа, который, как мы писали выше, считал себя преемником гумилёвского творчества. В этой цитате также очевиден скрытый упрек поэту в декоративности, в том, что его образы и тематика разрывают связь с реальностью, которая, наконец появившаяся в его творчестве, «прекраснее всего того, что ему мерещилось до cux nор» [Адамович 1999:90]. Критик словно бы призывает Оцупа твердо стоять ногами на земле, не отрываться от реальности, понять, что окружающий мир гораздо интереснее и лучше вымышленных стран и путешествий в прошлое. Здесь нужно отметить, что и Гумилёва современники не раз упрекали в излишней декоративности, экзотизме, достаточно вспомнить отзыв о книге «Романтические цветы» Анненского, творчество которого можно назвать ориентиром для всех акмеистов. Он, так же, как и Адамович в этой статье, считал, что все составляющие сборника Гумилёва - декорация, что в его книге «нет ни древнего востока, ни тысячелетнего тумана: бульвар, bec Aler, кусок ещё влажного от дождя асфальта перед кафе - вот и вся декоращия «ассирийского романа» [Анненский 1995:347-348 Анненский И. О романтических цветах // Н. С. Гумилёв: pro et contra. - СПб. : РХГИ, 1995. C. 347-349]. Поэтому мы считаем, что замечания Адамовича о поэзии Оцупа в очередной раз демонстрируют его близость поэтике Гумилёва. Так же важно обратить внимание на то, что критик отмечает, что стихотворения, в которых мир предстает в своей прекрасной простоте, мужественности позволяет читателю проникнуться доверием к Оцупу и понять, что «сейчас он вправе требовать внимания. Это один из тех немногих поэтов, которые рано или поздно вознаграждают слушателей за доверие к себе» [Адамович 1999:90].

Не вызывает сомнения, что критические отзывы Адамовича свидетельствуют о том, что ему близка лирика поэта. В то же время и Оцуп 
прислушивался к замечаниям критика. В частности, рассматривая поэму «Встреча», Адамович обратил внимание на отсутствие в ней единства, на то, что «в его книге есть, пожалуй, единство дневника, но не более того» [Адамович 1999:177]. Позже другую такую же автобиографическую поэму Оцуп, явно следуя рекомендации Адамовича, назвал «Дневник в стихах». «Встречу», вышедшую в 1928 году, критик назвал «одной из из caмbых удачных вещзей в намей поэзии за последние годы» [Адамович 1999:177]. Стихотворения поэмы он называет «легкими, точными, чистыли, сильньми, суховатыли» [Адамович 1999:177]. В поэме важна сила поэтического воздействия, которая заставляют каждого, прочитавшего eе, испытывать волнение перед искренностью автобиографического произведения: «Quasi-nоэма откровенно автобиографична. Оиуп рассказывает о детстве и изарскосельских садах с грустью. Его троянские мечты не менее меланхоличны. Но дальше голос крепнет, и душа становится суровее. Любовные стихи, со смутным и грустным женским образом в основе их, запоминаются почти все: их описательный реализм меток и мягок, а ирония, прорывающаяся то в напускной небрежности, то в еле ощутимом срыве тона, придает им «нежную горечь». За любовными следуют стихи итальянские, более патетические, где поэт опять вспоминает свое детство и Россию. И, наконец, самая «Встреча» - стихотворение о евреях и Мессии. Это, может быть, наиболее живые стихи из всех, написанных Оиупом. Нельзя обмануться, читая их: они внушены настоящим, высоким волнением - иначе никакое искусство не помогло бы поэту найти эти звуки, этот ритм, сразу овладевающий нами» [Адамович 1999:178]. Волнение поэта, о котором говорит Адамович, несомненно, передается и читателю, иначе, как объяснить восторженный тон статьи непредвзятого критика, который, как мы видели раньше, всегда стремиться к объективным оценкам.

Таким образом, рассмотренные статьи Адамовича об Оцупе на страницах парижского «Звена» позволяют нам говорить о том, что критик высоко оценивал лирику поэта, считая главной в ней те простоту, ясность, 
мужественность, искренность, которые характеризуют творчество близких ему акмеистов.

\section{БИБЛИОГРАФИЯ}

Адамович 1998 - Адамович Г. В. Литературные беседы. Книга первая («Звено» : 1923 - 1926) / Георгий Адамович. - СПб. : Алетейя, 1998. - 375 с.

Адамович 1999 - Адамович Г. В. Литературные беседы. Книга вторая («Звено» : 1926 - 1928) / Георгий Адамович. - СПб. : Алетейя, 1999. - 302 с.

Анненский 1995 - Анненский И. О романтических цветах / И. Ф. Анненский // Н. С. Гумилёв : pro et contra. - СПб. : РХГИ, 1995. C. 347-349.

Верник 2010 - Верник О. А. «Пленительная это фигура... в богатой замечательными людьми русской поэзии» (Н. А. Оцуп о Н. С. Гумилёве) / О. А. Верник // Вісник Луганського національного університету імені Тараса Шевченка: Філологічні науки. - Луганськ : ДЗ «ЛНУ імені Тараса Шевченка», 2010. - № 11 (198). - Ч. 1. - C. 209-220.

Гумилёв 1991 - Гумилёв Н. С. Сочинения : В 3 т. ; сост. Р. Д. Тименчик / Н. С. Гумилёв. - М. : Худож. лит., 1991. 